\title{
Changes in microbial communities in response to submarine groundwater input
}

\author{
Esther Garcés $^{1, *}{ }^{\text {, Gotzon Basterretxea }}{ }^{2}$, Antonio Tovar-Sánchez ${ }^{2}$ \\ ${ }^{1}$ Departament de Biologia Marina i Oceanografia, Institut de Ciències del Mar, \\ Consejo Superior de Investigaciones Científicas (CSIC), Pg. Marítim de la Barceloneta 37-49, 08003 Barcelona, Spain \\ ${ }^{2}$ Institut Mediterrani d'Estudis Avançats, Universidad de las Islas Baleares y el Consejo Superior de Investigaciones \\ Científicas (UIB-CSIC), Miquel Marqués 21, 07190 Esporles, Mallorca, Spain
}

\begin{abstract}
The effects of submarine groundwater on the native plankton populations of a coastal area were examined through a series of in situ groundwater addition experiments carried out during the summer in a Mediterranean embayment. Different percentages (4, 8, 10 and 12\%) of groundwater extracted from 2 intertidal coastal localities subjected to different land uses were added to picoplankton-dominated natural populations. The responses of the phytoplankton and bacterioplankton biomass were analyzed. The biomass of the phytoplankton community increased by as much as $96 \%$ above the mean initial value in ammonium-enriched groundwater and by a maximum of $400 \%$ in groundwater enriched in nitrate. Groundwater additions were followed by an enhancement in the biomass of all major autotrophic groups, with the most notable response in picophytoplankton, whereas bacterioplankton abundance increased only slightly. The abundance of diatoms was initially low although their growth rates increased faster than those of dinoflagellates, thus shifting the community composition towards a higher relative microphytoplankton proportion. An initial dinoflagellate community dominated by small naked dinoflagellates shifted to one characterized by a high abundance of Prorocentrum minimum. Our results demonstrate that, even in areas with low anthropogenic activity, groundwater discharges to the coast can effectively stimulate autotrophic plankton growth, thereby producing shifts in the microbial food-web structure of coastal waters. This, in turn, increases the possibility of outbreaks of opportunistic species, which can eventually result in harmful algal bloom episodes.
\end{abstract}

KEY WORDS: Submarine groundwater discharge - Coastal eutrophication - Phytoplankton biomass $\cdot$ Noxious bloom $\cdot$ Opportunistic algae $\cdot$ Nutrient input $\cdot$ Mediterranean Sea

Resale or republication not permitted without written consent of the publisher

\section{INTRODUCTION}

The Mediterranean Sea is among the most oligotrophic areas in the world (Redfield et al. 1963, Bethoux et al. 1992). Low nutrient availability and, particularly, inorganic phosphorus concentrations limit primary production (Thingstad \& Rassoulzadegan 1995, Thingstad et al. 1998). Consequently, chlorophyll concentrations in the sea's surface waters are low over large areas for most of the year $\left(<0.2 \mathrm{mg}\right.$ chlorophyll $\left.\mathrm{a} \mathrm{m}^{-3}\right)$. However, although the waters of the open Mediterranean Sea are charac- terized by low phytoplankton biomass, higher nutrient availability and phytoplankton abundance are observed in the nearshore areas, where episodes of harmful algal blooms (HABs) are frequent (Garcés \& Camp 2011). The enrichment of coastal waters occurs through inputs from rivers but also from continental runoff, groundwater discharges, aerosol deposition and anthropogenic inputs, the latter including wastewater discharges in populated coastal areas. Therefore, biological nearshore production is highly responsive to processes that deliver nutrients to surface waters, thus causing 
wide variability both across and within ecosystems (Cloern \& Jassby 2010).

Submarine groundwater discharge (SGD) along the coast serves as a major delivery pathway for nutrients and other chemical constituents. SGD, defined as the discharge of fresh and recirculated saline groundwater along the coastline at the land-sea interface (Burnett et al. 2006), is highly enriched in nutrients, metals, organic and inorganic carbon, and other compounds of natural or anthropogenic origin (Johannes 1980, Moore 1999). These terrestrially derived elements may be present in concentrations that are much higher than those typical of the receiving surface water bodies (Burnett et al. 2001, Taniguchi 2002, Kim \& Swarzenski 2005) and, therefore, their potential contribution to coastal budgets may be significant ( $\mathrm{Li}$ et al. 1999), especially in oligotrophic areas where other external nutrient sources are few (Shellenbarger et al. 2006). This is the case in the arid and semi-arid coasts of the Mediterranean region, where overland flow is low and often restricted to the wet season (Peixoto et al. 1982).

In nearshore coastal waters, the role of SGD in the transport of new nutrients is of particular importance because nearshore phytoplankton dynamics and, more specifically, some types of HABs require, among other factors, a significant source of nutrients (Paerl 1997). A growing body of evidence suggests that there is a relationship between SGD and algal blooms in coastal regions. Indirect measurements, for example, have shown that SGD affects coastal biological communities through different pathways: varying nutrient cycling in the coastal zone, changing the character of nutrient limitation by altering stoichiometric relationships, increasing primary production and altering phytoplankton community composition (Gobler \& Sanudo-Wilhelmy 2001, Hu et al. 2006, Lee \& Kim 2007, Liefer et al. 2009, Lee et al. 2010). However, obtaining direct evidence of the effects of SGD in coastal communities has been more challenging. de Sieyes et al. (2008) reported increases in chlorophyll a ( $\mathrm{chl} \mathrm{a}$ ) in response to the addition of nutrient-rich groundwater to natural phytoplankton populations grown under laboratory conditions (constant light). Also, Gobler \& Boneillo (2003) found that groundwater discharge may result in long-term eutrophication, with impacts on microphytoplankton communities. Effects of the groundwater in the microphytobentos and higher trophic levels have also been reported (Waska \& Kim 2010). However, because system-specific attributes (biotic and abiotic) synergistically act to modulate phytoplankton responses to enrichment, depending on the loads and characteristics of the receiving ecosystem, the responses of the coastal communities can vary markedly (Cloern 2001). The timing, amount, residence time, circulation and internal transformation of nutrient input determine a broad spectrum of phytoplankton community growth and bloom responses (Paerl 1997). Biological interactions and their role in the cycling of elements throughout the different compartments of the pelagic food web also influence the responses to groundwater enrichment.

Nutrient additions and altered nutrient ratios may play an important role in the aquatic environment by altering the existing balance among microorganisms that compete for nutrients, consequently shaping community structure by selecting for particular groups (Tilman et al. 1986, Berdalet et al. 1996). For example, studies have shown that under conditions in which algae and bacteria compete (unlimited phosphorus or nitrogen), diatom growth is favoured in the presence of excess silicate, and bacterial growth is favoured in the presence of excess organic carbon but not silicate (Thingstad et al. 1999, Thingstad \& Rassoulzadegan 1999, Zohary et al. 2005), although algal-bacterial interactions might be more intricate (Havskum et al. 2003). Structural changes can also occur within the autotrophic community. In mesocosm studies, Duarte et al. (2000) reported longterm shifts in the structure of nearshore Mediterranean summer communities, with dominance shifting from picophytoplankton to microphytoplankton, when nutrients were added ( $\mathrm{N}, \mathrm{P}$ and $\mathrm{Si})$. Thus, both algal-bacterial and algal-algal competition for nutrients are a key elements among the mechanisms controlling the structure of the pelagic food web.

The supply of nutrients and other elements from adjoining aquifers via groundwater diffuse discharges is potentially of primary relevance in the sustenance of coastal phytoplankton in the Mediterranean Sea (Basterretxea et al. 2010); yet, the potential impact on the whole planktonic community level is not well understood. The aim of the present study was to evaluate the response of a coastal microbial food web to the input of enriched groundwater obtained from 2 localities, one low-impacted and the other anthropogenically influenced. The short-term (days) responses of the coastal plankton communities were quantified and then compared with the responses to individual additions of inorganic phosphate, iron or both, based on the hypothesis that these macronutrients and micronutrients have a positive effect on microbial growth. Nutrient concentrations found to stimulate the growth of nearshore Mediterranean summer communities were also quantified. 


\section{MATERIALS AND METHODS}

\section{Study area}

Groundwater addition experiments were performed at the port of Cabrera, an inlet in the National Park of the Archipelago of Cabrera. Located $9 \mathrm{~km}$ southeast of the island of Mallorca, the Archipelago of Cabrera comprises 2 major islands and a number of small islets. The port of Cabrera is a sheltered and elongated $(\sim 1 \mathrm{~km})$ natural harbour with a maximum depth of $50 \mathrm{~m}$ at its offshore opening. Access to the National Park is restricted and land-based activities are reduced to maintenance operations. The prevailing summer meteorological conditions in Cabrera are characterized by low precipitation $\left(\sim 12 \mathrm{~mm} \mathrm{mo}^{-1}\right)$ and persistent sea breezes blowing from the SSW, which are notably reduced by the shelter provided by the steep hills around the harbour. The absence of rivers and significant point-source anthropogenic discharges make this bay a relatively simple system. In order to characterize nearshore and offshore Cabrera waters, samples were collected from a boat during the summer of 2008 at 29 stations distributed inside the port and in open waters around the archipelago, referred to in the text as nearshore and offshore stations, respectively. Nutrients, metals and chl a samples were analyzed as explained below.

\section{Groundwater and nutrient addition experiments}

In situ growth experiments were performed to test the response of coastal planktonic communities to the addition of groundwater and of inorganic nutrients. Surface seawater was collected in 501 acidwashed plastic carboys at 2 stations in the bay (Fig. 1) and prefiltered through a $60 \mu \mathrm{m}$ mesh to exclude large grazers. Seawater from Stn 1 was used in the 2008 experiments and from Stn 2 in the 2009 experiments. Incubations for each treatment were performed in triplicate 81 acid-washed PE bottles. The bottles were submerged $1 \mathrm{~m}$ below the sea surface in 3 nearby moorings located at approximately $2.5 \mathrm{~m}$ depth and incubated for $3 \mathrm{~d}$ to obtain growth rate estimates of the phytoplankton and bacterioplankton communities. Water temperature at the incubation depth was monitored with HOBO temperature loggers, and underwater irradiance was measured with a LI-193 quantum sensor. The bottles were sampled every $12 \mathrm{~h}$ for $\mathrm{chl} a$, bacterioplankton and phytoplankton, and inorganic nutrients. No more than $10 \%$ of a bottle's volume was removed over the course of the experiment. All experiments were carried out under clear skies (noon PAR = $2033 \pm 41 \mu \mathrm{mol} \mathrm{m}^{-2} \mathrm{~s}^{-1}$ ). Mean diel irradiance at the incubation depth was $683 \pm 185 \mu \mathrm{mol} \mathrm{m}{ }^{-2} \mathrm{~s}^{-1}$. Incubation temperatures generally oscillated between $24.5^{\circ} \mathrm{C}$ at night and $26.5^{\circ} \mathrm{C}$ at noon. Exceptionally, on


Fig. 1. Sampling stations. Grey crosses (Ъ): groundwater collection sites: Site 1, Santa Ponça; Site 2, Cabrera. P1 and P2: sea water collection sites for enrichment experiments (2008 and 2009) 
3 July 2008, the seawater temperature reached $27.5^{\circ} \mathrm{C}$.

Submarine groundwater for inoculation was obtained from 2 sites: Cabrera harbour and Santa Ponça beach (Fig. 1). Cabrera is considered a relatively pristine location within a national park, where the anthropogenic impact is low and groundwater enrichment is mainly from natural sources. By contrast, Santa Ponça is an intensively urbanised tourism-dedicated beach with groundwater enrichment from urban and agro-gardening sources. The beach is located in a small bay on the southern coast of Mallorca and has an average depth of $5.5 \mathrm{~m}$. Tourism resorts concentrate around the bay, with golf courses and agricultural land extending further inland. Detailed descriptions of land uses, significant anthropogenic pressures and impacted coastal areas are published in the administrative document (CAIB 2011). Moreover, Balearic nearshore waters have undergone eutrophication, as shown by significant nutrient-rich groundwater discharges along the shoreline and the recurrent summertime dinoflagellate outbreaks along the beach (Basterretxea et al. 2007). In Cabrera, the origin of the submarine groundwater was considered as low-impacted (LGW) whereas in Santa Ponça it was anthropogenically influenced (AGW1 and AGW2), consistent in each case with the type of land use (see CAIB 2011) and the level of inorganic nutrient concentration, specifically nitrate and ammonium, which are used as tracers of anthropogenic activities (Gobler \& Boneillo, 2003). Groundwater for the study was extracted in the intertidal zone from an approximate depth of $0.5 \mathrm{~m}$ below the seafloor using a stainless steel, shielded-screen drive-point piezometer (Retract-a-Tip, AMS; Charette \& Allen 2006) and then filtered through GF/F fiberglass filters to remove particles. Prior to the inoculation, salinity was equilibrated to that in seawater by adding $\mathrm{NaCl}$ (Merck, reagent grade quality).

In situ growth experiments were designed as follows. Three experiments consisted of the graduated addition of groundwater from the 3 extractions (AGW1, LGW and AGW2; Fig. 3) to seawater to yield final concentrations $(\mathrm{v} / \mathrm{v})$ of $4,8,10$ and $12 \%$
(Expt 1 with AGW1, Expt 2 with LGW and Expt 3 with AGW2). In 3 other independent experiments, the inorganic nutrients phosphate, iron or both $(\mathrm{P}, \mathrm{Fe}$ or $\mathrm{P}+\mathrm{Fe}$, respectively) were added to seawater using $1 \mu \mathrm{mol} \mathrm{l}{ }^{-1} \mathrm{NaH}_{2} \mathrm{PO}_{4} \cdot \mathrm{H}_{2} \mathrm{O}$ and $10 \mu \mathrm{mol} \mathrm{l}^{-1} \mathrm{FeCl}_{3} \cdot 6 \mathrm{H}_{2} \mathrm{O}$.

\section{Chl $a$, inorganic nutrients and metals analysis}

Chl a samples were collected in all experiments on GF/F filters and stored frozen. The samples were filter-extracted in acetone for $48 \mathrm{~h}$ and analyzed in a Turner Designs fluorometer (Yentsch \& Menzel 1963). Samples for the estimation of inorganic nutrients (ammonium, nitrate, phosphate and silicate) were prefiltered through Whatman GF/F filters, stored at $-20^{\circ} \mathrm{C}$ and further determined with an autoanalyzer (Alliance Evolution II) using standard colorimetric techniques (Grasshoff et al. 1983). Samples for trace metals $(\mathrm{Cu}, \mathrm{Fe}, \mathrm{Mo}, \mathrm{Ni}, \mathrm{Pb}$ and $\mathrm{Zn})$ in offshore and nearshore waters and groundwater for
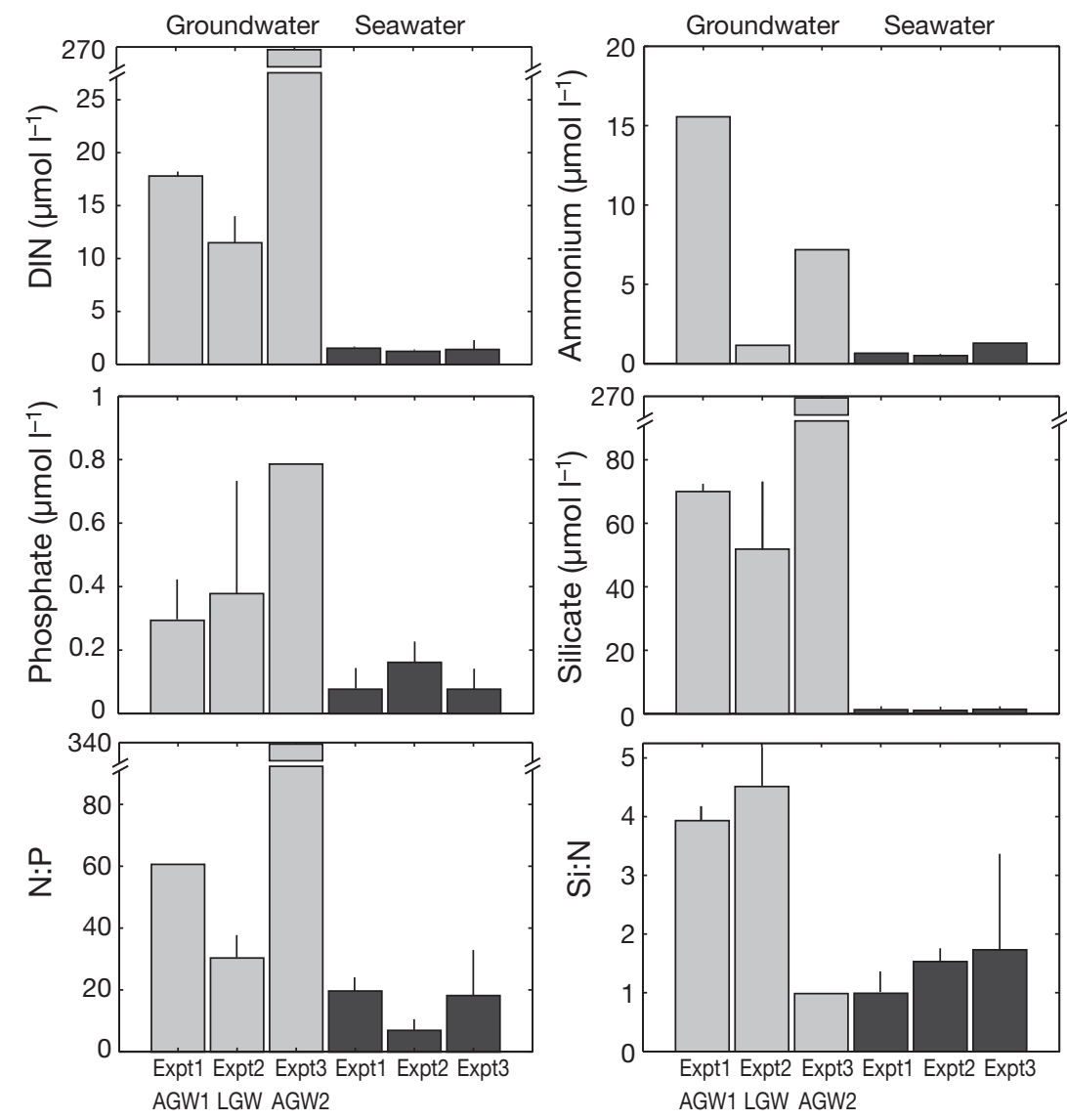

Fig. 2. Dissolved inorganic nitrogen (DIN), ammonium, phosphate, silicate, and N:P and Si:N ratios in low-impacted (LGW) and anthropogenically influenced (AGW1 and AGW2) groundwater (grey) and seawater (black) used for the experiments 
Expt 3 were collected using clean protocols (Montluçon \& Sañudo-Wilhelmy 2001). Water was collected in acid-washed Teflon tubing connected to a peristaltic pump, with acid-washed C-flex tubing (Cole Parmer) in the pump head. Samples were filtered through an acid-washed $0.22 \mu \mathrm{m}$ polypropylene calyx capsule filter and collected in acidcleaned $0.5 \mathrm{l}$ LDPE bottles. Trace-metal samples were acidified to $\mathrm{pH}<2$ with ultrapure grade $\mathrm{HCl}$ (Merck) in a class-100 HEPA laminar flow hood and stored for at least 1 mo before extraction. Metals were preconcentrated by the APDC/DDDC organic extraction method of Bruland et al. (1979), and analyzed by ICP-AES (Perkin Elmer Optima 5300 DV).

\section{Microplankton, nanoplankton and bacterioplankton}

In Expt 3, samples were collected for the identification and quantification of microplankton assemblages and were maintained in Lugol's-iodine solution (experimental samples), sedimented ( $24 \mathrm{~h}$ ), and a suitable area was quantified using a Leica-Leitz DM-IL inverted microscope (Andersen \& Throndsen 2003). For flow-cytometric quantification of bacterioplankton, Prochlorococcus spp., Synechoccocus spp. and picoeukaryotes, $2 \mathrm{ml}$ of the samples were fixed in the dark for $30 \mathrm{~min}$ with paraformaldehyde plus glutaraldehyde (1 and $0.05 \%$ final concentrations, respectively), stored in liquid nitrogen in situ, and transferred after arrival in the laboratory to a $-80^{\circ} \mathrm{C}$ freezer. The samples were analyzed with standard protocols on a Becton-Dickinson FACScalibur flow cytometer following the recommendations of Gasol \& Del Giorgio (2000). Briefly, unfrozen samples were stained with Syto 13 (Molecular Probes), mixed with yellow-green latex beads (Polyscience), and run at low speed until 10000 events had been registered in a right-angle side scatter (SSC) vs. green fluorescence (FL1, at $530 \pm 30 \mathrm{~nm}$ ) plot. Orange and red fluorescence were used to discriminate among the populations. The presence of nanoflagellates was detected by the observation of cytometric plots and identified as autotrophic nanoflagellates according to their flow cytometric fluorescence characteristics and further epifluorescence microscopy. Discrete samples were filtered through $0.6 \mu \mathrm{m}$ Nucleopore black polycarbonate filters and stained with DAPI at a final concentration of $5 \mathrm{\mu g} \mathrm{m}{ }^{-1}$. The filters were then placed on glass slides with a drop of fluorescent oil and observed by Nikon epifluorescence microscopy under UV radiation and blue light. Autotrophic nano- flagellates were confirmed by their red-orange fluorescence and plastidic structures and quantified by flow cytometry as described for bacteria.

\section{Growth rates}

Species group-specific net growth rates $\left(\mathrm{d}^{-1}\right)$ were calculated using the algorithm $\mu=\left(\ln N_{0} / \ln N_{\mathrm{t}}\right) / t$, where $N_{0}$ and $N_{\mathrm{t}}$ are initial and final cell densities, respectively, and $t$ is the time interval in days (Guillard 1973).

\section{RESULTS}

\section{Cabrera nearshore and offshore waters}

Offshore values of dissolved inorganic nutrients (DIN) and chl a were low, in the range of those reported for the area during the summer period (Vives 1993). Except for phosphate concentrations, significant differences in DIN and chl a concentrations ( $t$ - test, $\mathrm{p}<0.0001$ ) were determined between nearshore and offshore stations, suggesting nearshore enrichment sources and a phytoplankton biomass response to this enrichment (Fig. 2). Regarding micronutrient trace metals, similar concentrations of $\mathrm{Mo}$ and $\mathrm{Ni}$ were measured nearshore (Mo: $122.7 \mathrm{nmol} \mathrm{l}^{-1}$; Ni: $2.7 \mathrm{nmol} \mathrm{l}^{-1}$ ) and offshore (Mo: $127.1 \mathrm{nmol} \mathrm{l}^{-1}$; Ni: $3.8 \mathrm{nmol} \mathrm{l}^{-1}$ ); however, the concentrations of the other measured trace metals, i.e. $\mathrm{Cu}$, $\mathrm{Fe}, \mathrm{Pb}$ and $\mathrm{Zn}$, were 2, 1.4, 9.6 and 3.8 times higher, respectively, at nearshore than at offshore stations (Table 1).

\section{Groundwater and seawater macronutrients and micronutrients in the nutrient addition experiments}

The groundwater used for the addition experiments was rich in several inorganic nutrients and trace metals but its composition notably varied depending on the source, either low-impacted (LGW) or anthropogenically influenced (AGW; Fig. 3, Table 1). The extent of the anthropogenic influence on the obtained groundwater was determined based on both the ammonium concentration, which was high in the groundwater examined in Expts 1 and 3 (15 and $7 \mu \mathrm{mol} \mathrm{l}^{-1}$, respectively), and the low nitrate/ nitrite ratio (14) of the groundwater from Expt 3 (Expt3-AGW2), which was the lowest in all groundwater samples tested. Both LGW and AGW were par- 

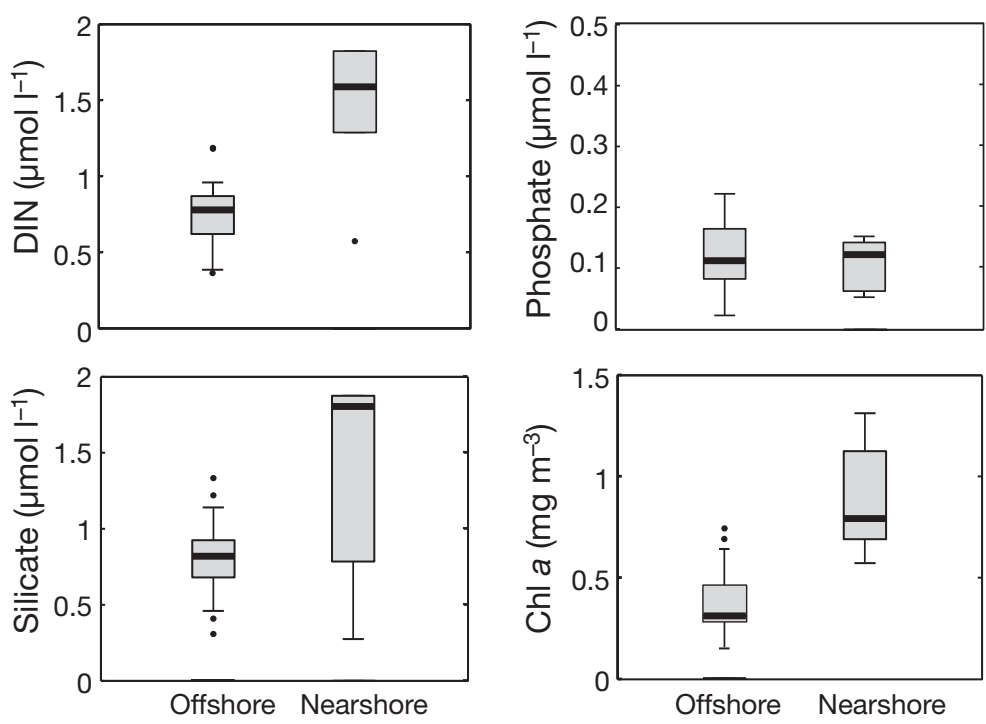

Fig. 3. Box-whisker plot of nearshore and offshore dissolved inorganic nitrogen (DIN), phosphate, silicate and chl a concentrations during the summer in Cabrera $(\mathrm{n}=29)$. Box plots show the median values (line), 25 and $75 \%$ quantiles (box), 5 and 95\% quantiles (whiskers), and outliers (dots)

ceeded those in seawater (Table 1). In contrast, inorganic nutrient concentrations in the natural seawater used for the incubations were modest and similar in all 3 experiments.

Differences in the inorganic nitrogen and phosphorous concentrations in the groundwater resulted in $\mathrm{N}: \mathrm{P}$ ratios higher (ratios from 30 to 340) than the Redfield N:P ratio in the experiments (Fig. 3). The low inorganic phosphorus levels measured in the seawater used for the addition experiments contributed to high inorganic N:P ratios and a possibly $\mathrm{P}$ limitation. High $\mathrm{Si}$ concentration in groundwater resulted in high $\mathrm{Si}: \mathrm{N}$ ratios. Although a balanced Si:N ratio was observed in the seawater used for the addition experiments, groundwater addition probably contributed to high silicate availability. In the case of $\mathrm{Fe}, \mathrm{P}$ and $\mathrm{P}+\mathrm{Fe}$ addition, the low inorganic phosphorus

ticularly highly enriched in Si (from 52 to $264 \mu \mathrm{mol}$ $\mathrm{l}^{-1}$ ), with concentrations 1 to 2 orders of magnitude greater than in seawater. Similarly, the concentrations of $\mathrm{P}, \mathrm{Fe}, \mathrm{Pb}, \mathrm{Zn}$ and $\mathrm{Ni}$ also markedly ex-

Table 1. Mean $( \pm \mathrm{SD})$ trace metals in the offshore $(\mathrm{n}=18)$, nearshore $(\mathrm{n}=2)$ waters of Cabrera during 2008 and in the anthropogenically influenced groundwater used in Expt 3 (Expt3-AGW2)

\begin{tabular}{|c|c|c|c|}
\hline Metal & Offshore & Nearshore & Expt3-AGW2 \\
\hline $\mathrm{Cu}\left(\mathrm{nmol} \mathrm{l}^{-1}\right)$ & $11.3 \pm 5.2$ & $23.0 \pm 18.1$ & 28.7 \\
\hline $\mathrm{Fe}\left(\mathrm{nmol} \mathrm{l}^{-1}\right)$ & $10.0 \pm 4.6$ & $14.2 \pm 2.1$ & 87.7 \\
\hline $\mathrm{Pb}\left(\mathrm{pmol} \mathrm{l}^{-1}\right)$ & $123.9 \pm 13.6$ & $1191.2 \pm 162.0$ & 2949.6 \\
\hline $\mathrm{Zn}\left(\mathrm{nmol} \mathrm{l} \mathrm{l}^{-1}\right)$ & $5.8 \pm 2.2$ & $22.0 \pm 4.3$ & 114.4 \\
\hline $\mathrm{Mo}\left(\mathrm{nmol} \mathrm{l}^{-1}\right)$ & $127.1 \pm 10.3$ & $122.7 \pm 0.1$ & 44.3 \\
\hline $\mathrm{Ni}\left(\mathrm{nmol} \mathrm{l}^{-1}\right)$ & $3.8 \pm 0.2$ & $2.7 \pm 0.9$ & 35 \\
\hline
\end{tabular}

and nitrogen levels present in the seawater used for the addition experiments led to a high inorganic N:P ratio of 22. After $\mathrm{P}$ and $\mathrm{P}+\mathrm{Fe}$ additions, the inorganic $\mathrm{N}: \mathrm{P}$ ratio decreased by approximately 1 (data not shown).

\section{Growth rates of phytoplankton biomass and group abundances}

Initial phytoplankton ( $\mathrm{chl} \mathrm{a)} \mathrm{biomass} \mathrm{was} \mathrm{0.84,} 1.26$ and $0.3 \mathrm{mg} \mathrm{chl} \mathrm{a} \mathrm{m}^{-3}$ in graduated groundwater addition Expts 1, 2 and 3, respectively. With some exceptions (i.e. $4 \%$ in Expts 1 and 2), groundwater additions significantly increased phytoplankton growth rates, as determined based on chl a variation relative to control treatment (post hoc Tukey's test after a sig-
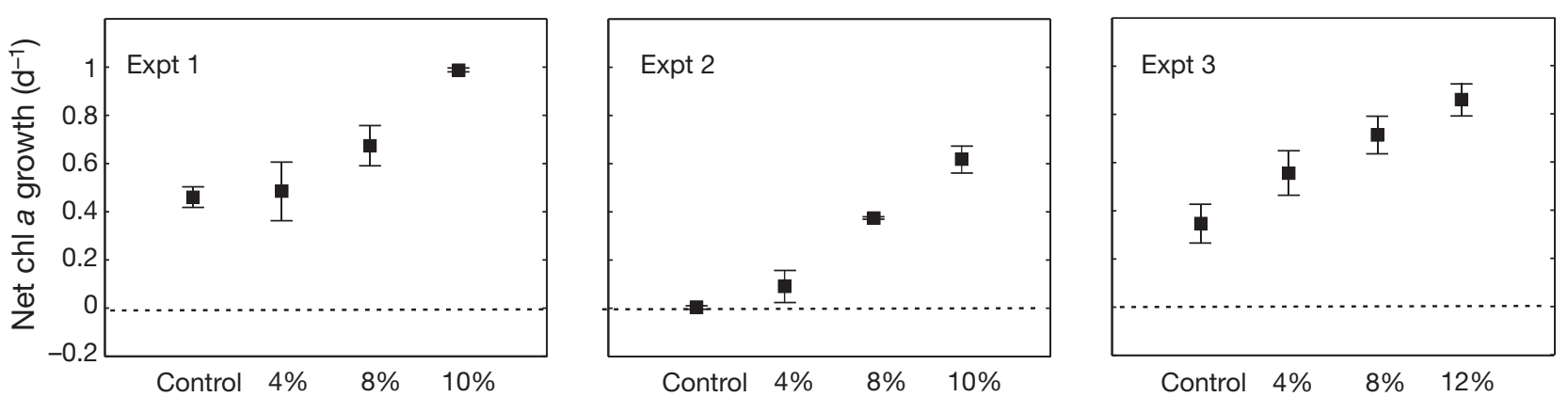

Fig. 4. Mean $( \pm \mathrm{SD})$ net growth rates, measured as chl $a$, following either the addition of different percentages of groundwater or no addition (control) in 3 experiments. Expts 1 and 3: addition of anthropogenically influenced groundwater extracted from 2 different sites (AGW1 and AGW2); Expt 2: addition of low-impacted groundwater (LGW) 
nificant ANOVA, $\mathrm{p}<0.001$; Fig. 4). Phytoplankton biomass reached maximum values ranging from 96 to $400 \%$ above the mean initial value. Maximum increases occurred in the inoculation of $12 \%$ groundwater in Expt3-AGW2, which was characterized by an initially low biomass inoculum and groundwater enriched in nitrate. Chl a growth was saturated at the $12 \%$ groundwater addition in this experiment. The addition of the AGW orLGW yielded similar responses with respect to chl a growth, as the differences between the 3 slopes obtained from a plot (Fig. 3). The addition of the AGW or LGW yielded similar responses with respect to chl a growth, as the differences between the 3 slopes obtained from the plot of chl a growth-rate response versus percentage of groundwater addition (Fig. 3) were not significant (ANCOVA, $F=0.5633, \mathrm{p}=0.5759$ ). The remarkable increase in the chl a growth rate that occurred in the groundwater gradient corresponds to a wide range of measured nutrients: 2.2 to $10 \mu \mathrm{mol} \mathrm{DIN} \mathrm{l}^{-1}, 0.07$ to

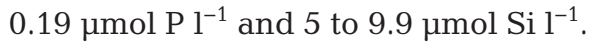

The additions of $\mathrm{P}$ and $\mathrm{P}+\mathrm{Fe}$ increased phytoplankton growth rates (based on chl a) relative to the control treatment, but no change was observed following the addition of only Fe ( $p<0.001$; Fig. 5). Although the phosphate concentration in the $12 \%$ groundwater treatment was 1 order of magnitude lower, phytoplankton growth rates were higher than in the $\mathrm{P}$ and $\mathrm{P}+\mathrm{Fe}$ additions $(400 \%$ increase above the mean initial value in $12 \% \mathrm{AGW}$ vs. a $46 \%$ increase in the $\mathrm{P}$ and $\mathrm{P}+\mathrm{Fe}$ additions).

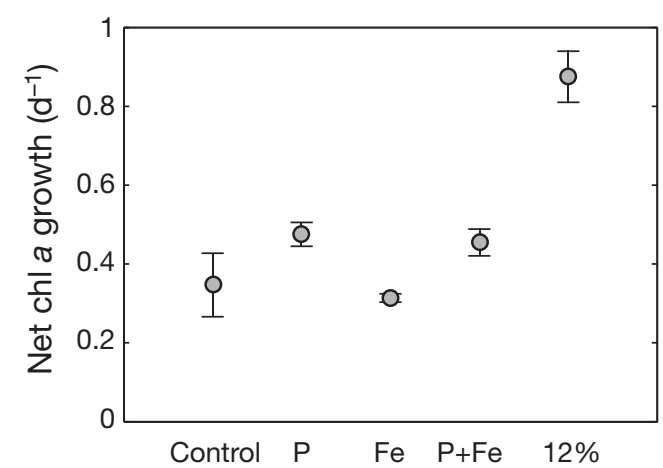

Fig. 5. Mean $( \pm \mathrm{SD})$ net growth rates, measured as chl $a$, following the addition of $12 \%$ groundwater, no addition (control), and $\mathrm{P}, \mathrm{Fe}$ and $\mathrm{P}+\mathrm{Fe}$ nutrient additions

higher than those in the seawater control (post hoc Tukey's test, $\mathrm{p}<0.001$ ). Similar trends were observed for Prochlorococcus spp. (data not shown). Groundwater additions increased the growth rates of highDNA bacterioplankton relative to the control treatment (Fig. 6), in which total bacterioplankton increased as well (data not shown) but with a lower slope than that of picoplankton (ANCOVA, p < 0.0001). In the $\mathrm{P}, \mathrm{P}+\mathrm{Fe}$ and Fe additions, bacterioplankton growth rates relative to the control treatment were increased by the $\mathrm{P}$ and $\mathrm{P}+\mathrm{Fe}$ additions, but no change was observed following the addition of only Fe ( $p<0.001$; Fig. 7). Bacterioplankton growth rates in $\mathrm{P}+\mathrm{Fe}$ additions were comparable to those in the $12 \%$ groundwater treatment AGW2. P, $\mathrm{Fe}$, and $\mathrm{P}+\mathrm{Fe}$ additions raised Synechoccocus spp.

\section{Bacterioplankton and phytoplankton dynamics}

The initial bacterioplankton, picoplankton, nanoplankton and microplankton abundances in Expt 3 are listed in Table 2. Picoplankton and nanoplankton represented approximately $98 \%$ of the total population of autotrophic phytoplankton, with Synechoccocus spp. accounting for $90 \%$ of picoplankton abundance. The increased biomass of the autotrophic community (chl a growth) was largely attributable to that of the picoplankton community in response to the nutrient enrichment provided by anthropogenic groundwater (AGW2). The growth rates of Synechoccocus spp. in AGW2 were significantly
Table 2. Summary of initial values of chlorophyll a concentration (mg chl a m $\mathrm{m}^{-3}$ ) and cell abundance of bacterioplankton, picoplankton, nanoplankton (2 to $20 \mu \mathrm{m})\left(\right.$ cells ml ${ }^{-1}$ ) and microplankton $(>20 \mu \mathrm{m})\left(\right.$ cells $\left.\mathrm{l}^{-1}\right)$ during nutrient addition Expt 3. Picoplankton comprises prochlorophytes and Synechoccocus spp., both measured by flow cytometry. Diatom and dinoflagellate taxa are included within the microplankton, and nauplii, ciliate and heterotrophic dinoflagellate are included within the heterotrophs

\begin{tabular}{|lccc|}
\hline Functional group & & Mean & SD \\
\hline- & Chlorophyll a & 0.30 & 0.02 \\
Bacterioplankton & High DNA & $1.46 \times 10^{5}$ & $1.20 \times 10^{4}$ \\
& Total & $3.01 \times 10^{5}$ & $2.49 \times 10^{4}$ \\
Autotrophic picoplankton & Synechoccocus & $1.50 \times 10^{4}$ & $0.38 \times 10^{3}$ \\
& Prochlorococcus & 1502 & 130 \\
& Other & 167 & 32 \\
Nanoplankton $(2$ to $20 \mu \mathrm{m})$ & Autotrophs & 65 & 24 \\
Microplankton $(>20 \mu \mathrm{m})$ & Diatoms & 150 & 71 \\
& Dinoflagellates & 2390 & 240 \\
& Other autotrophs & 160 & 60 \\
& Heterotrophs & 270 & 99 \\
\hline
\end{tabular}



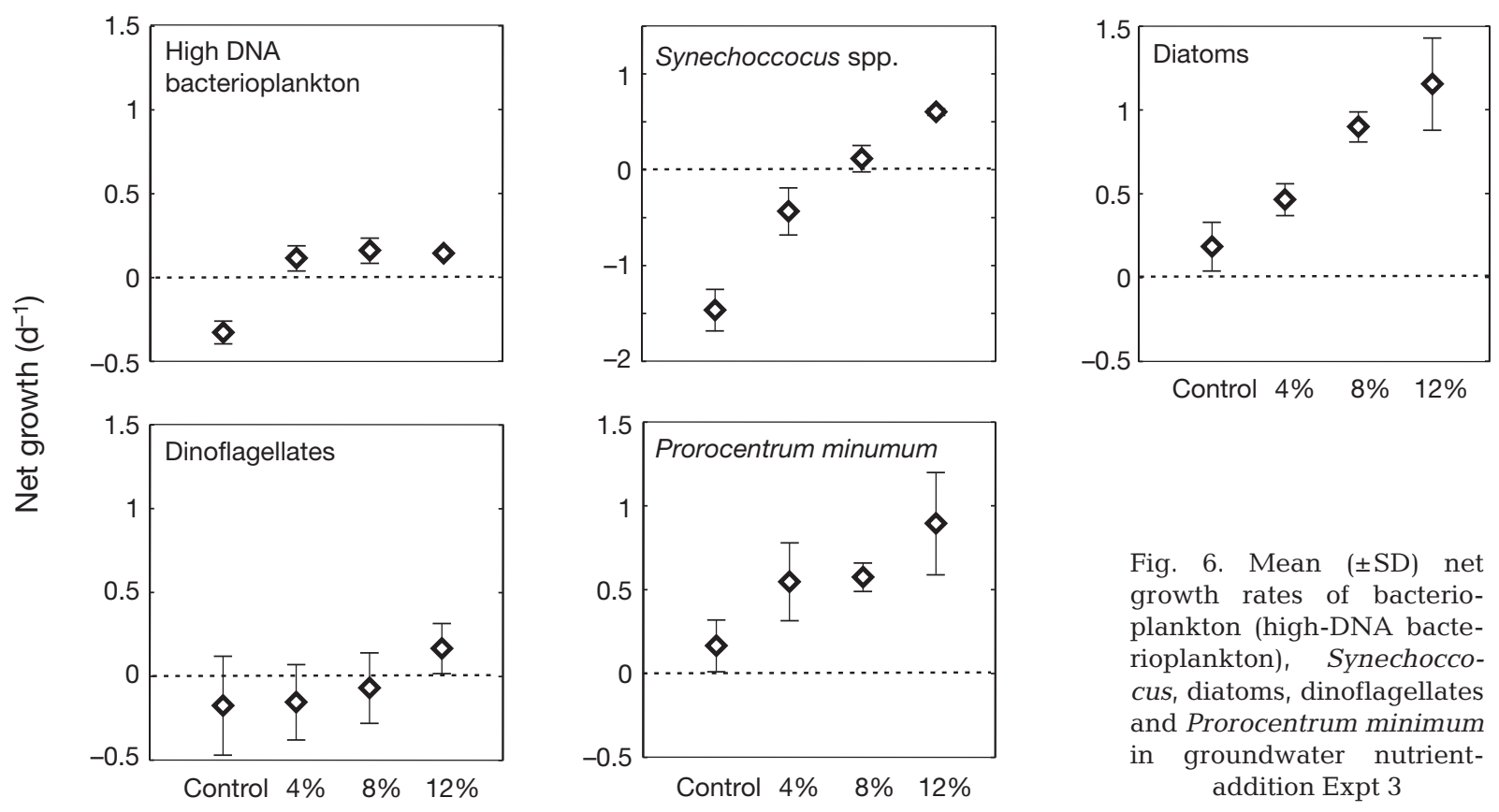

\begin{abstract}
Fig. 6. Mean $( \pm \mathrm{SD})$ net growth rates of bacterioplankton (high-DNA bacterioplankton), Synechoccocus, diatoms, dinoflagellates and Prorocentrum minimum in groundwater nutrientaddition Expt 3
\end{abstract}

growth rates relative to the control treatment, but with high variability in the $\mathrm{P}$ and $\mathrm{P}+\mathrm{Fe}$ treatment. $\mathrm{P}$, $\mathrm{P}+\mathrm{Fe}$ and $\mathrm{Fe}$ additions were significantly lower $(\mathrm{p}<$ 0.001 ) than the $12 \%$ groundwater treatment.

The microplankton component mainly consisted of dinoflagellates (94\%), mostly naked species, small flagellates (generally $<5 \mu \mathrm{m}$ ) and small solitary pennate diatom species. Microplankton components of the community responded differently to the graduated addition of nutrients of anthropogenic groundwater (AGW2). Although the growth rates of diatoms significantly increased in response to AGW2 (Fig. 6), this was not the case in the dinoflagellate group ( $p=0.0785)$. Nevertheless, among the latter, Prorocentrum minimum exhibited a significant $(\mathrm{p}<0.001)$ response relative to the seawater control. The initial dinoflagellate community was dominated by small naked dinoflagellates but finally
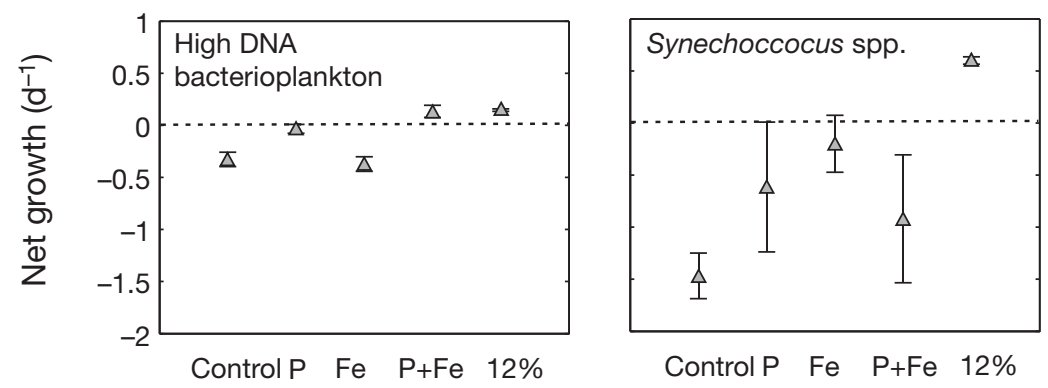

Fig. 7. Mean $( \pm \mathrm{SD})$ net growth rates of high-DNA bacterioplankton and Synechoccocus spp. following the addition of $12 \%$ groundwater, no addition (control), and $\mathrm{P}, \mathrm{Fe}$ and $\mathrm{P}+\mathrm{Fe}$ in Expt 3 changed to a high abundance of P. minimum (46\% dinoflagellate community).

Overall, the graduated addition of nutrients of anthropogenic groundwater (AGW2; Fig. 6) yielded different growth responses in the bacterioplankton and phytoplankton groups. The differences between the slopes obtained in plots of growth-rate response vs. percent groundwater addition were highly significant (ANCOVA, $F=18.3619$, p < 0.0001).

\section{DISCUSSION}

The present study confirms that coastal enrichment through groundwater favours autotrophic plankton growth and drives short-term changes in the microbial food-web structure. Increased nutrient availability fuelled the growth of the original summer picoplankton population and other microphytoplankton groups such as diatoms. Diatoms are not characteristic of summer phytoplankton assemblages in the Mediterranean, but nonetheless promptly responded to enhance nutrient availability in our experiments. Autotrophic plankton growth, favoured by increased nutrient availability, partially explains the shoreward biomass gradients and differentiated phytoplankton communities existing in the nearshore waters of 
the Mediterranean Sea where groundwater exchanges are enhanced (e.g. the nearshore waters of beaches and sedimentary environments). This is exemplified by our study area, where the coastal area is non-homogeneous as demonstrated by significantly higher concentrations of dissolved inorganic nutrients and chl a inshore than offshore.

As in other coastal areas, nitrate and ammonium were the dominant forms of inorganic nitrogen found in the groundwater of the study area (Valiela \& Costa 1988, Gobler \& Sañudo-Wilhemy 2001). Nitrate was predominant in the groundwater of Cabrera (LGW) whereas high ammonium concentrations were present in groundwater from Santa Ponça (AGW1 and AGW2). The contrasting behaviours of nitrate and phosphate in the respective groundwater systems, mainly caused by the different labilities of $\mathrm{N}$ and $\mathrm{P}$ in sandy substrates, typically result in a strong increase in the ratio of dissolved inorganic N:P (see Slomp \& Van Cappellen 2004 for a compilation of measured groundwater fluxes), as has been measured in our groundwater samples. Groundwater is known to also be naturally rich in silicate and other bioactive elements, such as Fe, Ni and Zn. This could be especially relevant for changes in Fe concentrations in the seawater in the study area, because the area was a carbonate-sediment region where inputs of Fe are limited, and Fe limitation has been suggested for marine organisms such as Posidonia oceanica (Marbà et. al (2007). Results from nutrient addition in Expt 3 indicated not only an Fe limitation in the Synechoccocus population, but also a co-limitation due to macronutrient and micronutrient shortage. In fact, picoplankton growth was found to be promoted by the mixture of dissolved constituents in groundwater rather than by a single macronutrient or micronutrient. Efforts to analyze the components of the groundwater were insufficient to identify the components that promote higher autotrophic growth in the groundwater addition than the simple addition of $\mathrm{P}$ and $\mathrm{P}+\mathrm{Fe}$. Other biogenic components such as organic compounds, vitamins (e.g. B12 or B1) or other trace elements (e.g. Co) also need to be investigated.

The increase in chl a biomass that occurred in the groundwater gradients represents a wide range of nutrients but with realistic concentrations of nitrate and phosphate for coastal waters. Such nutrient concentrations, shown to boost phytoplankton biomass, are quite frequent in Mediterranean beaches of the Balearic Islands (Basterretxea et al. 2007, GarciaSolsona et al. 2010). Although our results showed that nutrient enrichment through groundwater favoured autotrophic plankton growth in the area of study, we are aware that ecological responses can differ depending on groundwater composition (and land uses), flow and discharge conditions (e.g. diffusive, continuous and seasonal), and the characteristics of the receiving waters. The initial characterisation of the added groundwater revealed differences in the forms of specific inorganic nutrients, such as nitrate and ammonium. However, variations in the available nitrate source did not notably influence the chl a specific growth rate. This finding has important implications in the context of the environmental management of coastal zones (i.e. European Water Framework Directive, EC, 2000). In assessments of eutrophication, there are tools such as biological elements to be evaluated. One of the most recognised eutrophication assessment methods is using chl a as a proxy for phytoplankton biomass. As eutrophication can be natural, human-driven or both, it is necessary for assessment purposes to associate variations in chl a concentrations with the driving forces. Here we showed that chl a can be formed in response to groundwater inputs, independently of groundwater origin and land use in the catchment area. Therefore, human pressures on the marine environmental can lead to similar changes and impacts such as natural nutrient enrichment, which further complicate management measures.

The increase in biomass of all major autotrophic groups in the groundwater addition experiments was largely attributable to an increase in picoplankton biomass. In contrast to the autotrophic biomass, there was a slight increase in bacterioplankton biomass. As in most oligotrophic oceanographic regions, biomass levels in the Mediterranean Sea are generally associated with the dominance of cyanobacteria, prochlorophytes and tiny flagellates. In our experiment, among the picoplankton, Synechoccocus reached high abundances and thus a major increase in biomass. As previously reported, Synechoccocus can use different $\mathrm{N}$ sources from the marine environment, with the adaptations of the different ecotypes optimized for the environment in which these sources are available (Glibert \& Ray 1990, Moore et al. 2002). A similar increase of picophytoplankton was described in mesocosm studies of summer coastal Mediterranean planktonic populations (Duarte et al. 2000). These authors showed that, at the highest nutrient loadings, the structure of the phytoplankton community shifted from an initial dominance of picophytoplankton to one of microphytoplankton in the long term. Our study confirms the response of summer picophytoplankton to the natural nutrient concentrations provided by groundwater sources. The 
difference among previous experiments and ours is that we performed short-term incubations, which, while minimizing bottle effects, do not allow assessment of the full potential of the natural microbial community. Nevertheless, it is plausible that, over a longer period, continuous groundwater inputs could lead to new equilibrium states in nearshore communities, resulting in alternative trophic interactions and differentiated phytoplankton assemblages.

The changes in microalgal community composition due to increased diatom growth observed during this study may have been a response to the ratios of dissolved inorganic nitrogen and dissolved silicate in groundwater. Silicate was probably the controlling nutrient in the community shift from diatoms to flagellates, whereas a similar increase in bacterioplankton with respect to diatoms was not observed. This situation could have been caused by competition between these 2 groups for available nutrients. Deficiencies in mineral nutrients limit the growth rate of heterotrophic bacteria, at least in P-deficient regions. In our study, silicate addition (and probably dissolved organic carbon limitation) was such that in the competition between bacteria and phytoplankton, the latter group was favoured. Competition is therefore one of several mechanisms that control the structure of the pelagic food web. The interactions between bacteria and photosynthetic organisms have not only been reported in the Mediterranean Sea but also in other marine pelagic environments. The strategy evolved by diatoms is particularly well suited for the rapid exploitation of short-term situations in which nutrient enrichment allows larger phytoplankton species to become established. For example, groundwater inputs may favour the growth of toxic diatoms, such as those of the Pseudo-nitzchia genus (Liefer et al. 2009), blooms of which have been associated with large coastal runoff or discharge events characterized by nutrient pulses. In the specific case of the Mediterranean Sea, the input of silicate through groundwater discharges could be relevant for diatom growth. Terrestrial sources reaching Mediterranean coastal areas have led to a general increase of $\mathrm{N}$ over the last several decades but, contrastingly, sources of silicon have remained relatively constant or have even decreased (see the review of Ludwig et al. 2009). The resulting changes in N:Si ratios have been related to shifts in species dominance within the phytoplankton assemblage and food-web structure (Smayda 1990). The input of silicate through groundwater discharges can temporarily and locally alleviate this shift, as has been demonstrated in our area (present study).
Other microphytoplankton groups in the natural sample, such as dinoflagellates, which are less abundant than nanoflagellates but more important in terms of carbon biomass due to their larger size, do not respond significantly to groundwater input. Although dinoflagellates are generally assumed to have low maximum growth rates (although not always; Smayda 1997) and therefore require more time to increase their biomass, our experiments showed that one species of dinoflagellate, Prorocentrum minimum, became dominant. $P$. minimum is an HAB species that has long been associated with eutrophication (Heil et al. 2005). Although the species can be mixotrophic (Stoecker et al. 1997), it is able to use ammonium as a source of $\mathrm{N}$ (Fan et al. 2003) and blooms of $P$. minimum have been linked to regions with relatively high anthropogenic contributions to dissolved organic $\mathrm{N}$ and $\mathrm{P}$ exports (such as fertilizers and manures in the case of DIN) (San Diego-McGlone et al. 2008, Glibert et al. 2008).

To conclude, we showed that groundwater inputs favour the growth of particular coastal marine groups or species, producing imbalances in the plankton community that could increase the occurrence of opportunistic species and the probability of HAB episodes. More specifically, this was the case at Santa Ponça, where the increased levels of DIN are induced by anthropogenically enriched groundwater discharges and blooms of phytoplankton are recurrent. However, even naturally enriched groundwater can fuel algal growth and promote the proliferation of HABs in nearshore Mediterranean coastal areas.

Acknowledgements. This work was supported by the CABIARCA (MARM 27/2007) and EDASE (MICINN, CGL200800047/BTE) projects. E. Garcés was supported by a Ramon y Cajal contract of the Spanish Ministry of Science and Innovation (MICINN). We thank A. Massanet and I. Álvarez for their help in sample collection and analysis.

\section{LITERATURE CITED}

Andersen P, Throndsen J (2003) Estimating cell numbers. In: Hallegraeff GM, Anderson DM, Cembella AD (eds) Manual on harmful marine microalgae. UNESCO, Paris, p 99-129

> Basterretxea G, Garcés E, Jordi A, Anglès S, Masó M (2007) Modulation of nearshore harmful algal blooms by in situ growth rate and water renewal. Mar Ecol Prog Ser 352: 53-65

Basterretxea G, Tovar-Sanchez A, Beck A, Masqué P and others (2010) Submarine groundwater discharge to the coastal environment of a Mediterranean Island (Majorca, Spain): ecosystem and biogeochemical significance. Ecosystems 13:629-643

Berdalet E, Marrasé C, Estrada M, Arin L, Mac L, Lean M 
(1996) Microbial community responses to nitrogen- and phosphorus-deficient nutrient inputs: microplankton dynamics and biochemical characterization. J Plankton Res 18:1627-1641

Bethoux JP, Morin P, Madec C, Gentili B (1992) Phosphorus and nitrogen behaviour in the Mediterranean Sea. DeepSea Res A 39:1641-1654

Bruland KW, Franks RP, Knauer GA, Martin JH (1979) Sampling and analytical methods for the determination of copper, cadmium, zinc, and nickel at the nanogram per liter level in sea-water. Anal Chim Acta 105:233-245

Burnett W, Kim G, Lane-Smith D (2001) A continuous monitor for assessment of ${ }^{222} \mathrm{Rn}$ in the coastal ocean. J Radioanal Nucl Chem 249:167-172

> Burnett WC, Aggarwal PK, Aureli A, Bokuniewicz H and others (2006) Quantifying submarine groundwater discharge in the coastal zone via multiple methods. Sci Total Environ 367:498-543

CAIB (2011) Plan hidrológico de la demarcación Illes Balears. In: Hídrics DGDR (ed) Govern De Les Illes Balears. Balears Conselleria de Medi Ambient i Mobilitat, Palma

> Charette MA, Allen MC (2006) Precision groundwater sampling in coastal aquifers using a direct push shielded screen well-point system. Ground Water Monit Remediat 26:87-93

> Cloern JE (2001) Our evolving conceptual model of the coastal eutrophication problem. Mar Ecol Prog Ser 210: 223-253

Cloern JE, Jassby AD (2010) Patterns and scales of phytoplankton variability in estuarine-coastal ecosystems. Estuar Coast 33:230-241

de Sieyes NR, Yamahara KM, Layton BA, Joyce EH, Boehm $A B$ (2008) Submarine discharge of nutrient-enriched fresh groundwater at Stinson Beach, California is enhanced during neap tides. Limnol Oceanogr 53: 1434-1445

> Duarte CM, Agusti S, Agawin NSR (2000) Response of a Mediterranean phytoplankton community to increased nutrient inputs: a mesocosm experiment. Mar Ecol Prog Ser 195:61-70

Fan C, Glibert PM, Alexander J, Lomas MW (2003) Characterization of urease activity in three marine phytoplankton species, Aureococcus anophagefferens, Prorocentrum minimum, and Thalassiosira weissflogii. Mar Biol 142:949-958

Garcés E, Camp J (2011) Habitat changes in the Mediterranean Sea and the consequences for harmful algal bloom formation. In: Stambler N (ed) Life in the Mediterranean Sea: a look at habitat changes. Nova Science Publishers, New York, NY, p 557-581

Garcia-Solsona E, Garcia-Orellana J, Masqué P, Garcés E and others (2010) Assessment of the karstic submarine groundwater and associated nutrient discharge in a Mediterranean coastal area using Ra isotopes (Balearic Islands, Spain). Biogeochemistry 97:211-229

Gasol JM, Del Giorgio PA (2000) Using flow cytometry for counting natural planktonic bacteria and understanding the structure of planktonic bacterial communities. Sci Mar 64:197-224

> Glibert PM, Ray RT (1990) Different patterns of growth and nitrogen uptake in two clones of marine Synechococcus spp. Mar Biol 107:273-280

Glibert PM, Mayorga E, Seitzinger S (2008) Prorocentrum minimum tracks anthropogenic nitrogen and phosphorus inputs on a global basis: application of spatially explicit nutrient export models. Harmful Algae 8:33-38

Gobler CJ, Boneillo GE (2003) Impacts of anthropogenically influenced groundwater seepage on water chemistry and phytoplankton dynamics within a coastal marine system. Mar Ecol Prog Ser 255:101-114

> Gobler CC, Sañudo-Wilhelmy SS (2001) Temporal variability of groundwater seepage and brown tide blooms in a Long Island embayment. Mar Ecol Prog Ser 217:299-309

Grasshoff K, Ehrhardt M, Kremling K (1983) Methods of seawater analysis. Verlag-Chemie, Weinheim, Germany

Guillard RRL (1973) Division rates. In: Stein JR (ed) Handbook of phycological methods: culture methods and growth measurements, Vol 1. Cambridge University Press, New York, p 289-312

Havskum H, Thingstad TF, Scharek R, Peters F and others (2003) Silicate and labile DOC interfere in structuring the microbial food web via algal-bacterial competition for mineral nutrients: results of a mesocosm experiment. Limnol Oceanogr 48:129-140

Heil CA, Glibert PM, Fan C (2005) Prorocentrum minimum (Pavillard) Schiller: a review of a harmful algal bloom species of growing worldwide importance. Harmful Algae 4:449-470

Hu C, Muller-Karger FE, Swarzenski PW (2006) Hurricanes, submarine groundwater discharge, and Florida's red tides. Geophys Res Lett 33:L11601 doi:10.1029/ 2055GL025449

Johannes RE (1980) Ecological significance of the submarine discharge of groundwater. Mar Ecol Prog Ser 3:365-373

Kim G, Swarzenski PW (2005) Submarine ground-water discharge (SGD) and associated nutrient fluxes to the coastal ocean. In: Liu KK, Atkinson L, Quinones R, Talaue-McManus L (eds) Carbon and nutrient fluxes in continental margins: a global synthesis. Springer-Verlag, New York, p 1-36

> Lee YW, Kim G (2007) Linking groundwater-borne nutrients and dinoflagellate red-tide outbreaks in the southern sea of Korea using a Ra tracer. Estuar Coast Shelf Sci 71: 309-317

Lee YW, Kim G, Lim W-A, Hwang D-W (2010) A relationship between submarine groundwater-borne nutrients traced by $\mathrm{Ra}$ isotopes and the intensity of dinoflagellate redtides occurring in the southern sea of Korea. Limnol Oceanogr 21:1-10

> Li L, Barry DA, Stagnitti F, Parlange JY (1999) Submarine groundwater discharge and associated chemical input to a coastal sea. Water Resour Res 35:3253-3259

Liefer JD, MacIntyr HL, Novoveska L, Smith WL, Dorsey CP (2009) Temporal and spatial variability in Pseudonitzschia spp. in Alabama coastal waters: A 'hot spot' linked to submarine groundwater discharge? Harmful Algae 8:706-714

Ludwig W, Dumont E, Meybeck M, Heussner S (2009) River discharges of water and nutrients to the Mediterranean and Black Sea: Major drivers for ecosystem changes during past and future decades? Prog Oceanogr 80:199-217

Marbà N, Calleja ML, Duarte CM, Alvarez E, Díaz-Almela E, Holmer M (2007) Iron additions reduce sulfide intrusion and reverse seagrass (Posidonia oceanica) decline in carbonate sediments. Ecosystems 10:745-756

Montluçon D, Sañudo-Wilhelmy SA (2001) Influence of net groundwater discharge on the chemical composition of a coastal environment: Flanders Bay, Long Island, New York. Environ Sci Technol 35:480-486 
Moore WS (1999) The subterranean estuary: a reaction zone of ground water and sea water. Mar Chem 65:111-125

Moore LR, Post AF, Rocap G, Chisholm SW (2002) Utilization of different nitrogen sources by the marine cyanobacteria Prochlorococcus and Synechococcus. Limnol Oceanogr 47:989-996

Paerl H (1997) Coastal eutrophication and harmful algal blooms: importance of atmospheric deposition and groundwater as 'new' nitrogen and other nutrient sources. Limnol Oceanogr 42:1154-1165

Peixoto JP, Almeida MD, Rosen RD, Salstein DA (1982) Atmospheric moisture transport and the water balance of the Mediterranean Sea. Water Resour Res 18:83-90

Redfield AC, Ketchum BH, Richards FA (1963) The influence of the organisms on the composition of sea-water. In: Hill MN (ed) The sea: ideas and observations on progress in the study of the seas, Vol 2. The composition of the sea-water. Comparative and descriptive oceanography. Interscience Publishers, New York, p 26-77

San Diego-McGlone ML, Azanza RV, Villanoy CL, Jacinto GS (2008) Eutrophic waters, algal bloom and fish kill in fish farming areas in Bolinao, Pangasinan, Philippines. Mar Pollut Bull 57:295-301 Medline

Shellenbarger GG, Monismith SG, Genin A, Paytan A (2006) The importance of submarine groundwater discharge to the nearshore nutrient supply in the Gulf of Aqaba (Israel). Limnol Oceanogr 51:1876-1886

Slomp CP, Van Cappellen P (2004) Nutrient inputs to the coastal ocean through submarine groundwater discharge: controls and potential impact. J Hydrol 295: 64-86

Smayda TJ (1997) Harmful algal blooms: their ecophysiology and general relevance to phytoplankton blooms in the sea. Limnol Oceanogr 42:1137-1153

Smayda TJ, White AW (1990) Has there been a global expansion of algal blooms? If so, is there a connection with human activities? In: Graneli E, Sundstroem B, Edler L, Anderson DM (eds) Toxic marine phytoplankton. Elsevier, p 516-517

Stoecker DK, Li A, Coats DW, Gustafson DE, Nannen MK (1997) Mixotrophy in the dinoflagellate Prorocentrum minimum. Mar Ecol Prog Ser 152:1-12

Editorial responsibility: Graham Savidge,

Portaferry, UK
Taniguchi M (2002) Tidal effects on submarine groundwater discharge into the ocean. Geophys Res Lett 29:1561 doi: 10.1029/2002GL014987

> Thingstad TF, Rassoulzadegan F (1995) Nutrient limitations, microbial food webs, and 'biological C-pumps': suggested interactions in a P-limited Mediterranean. Mar Ecol Prog Ser 117:299-306

Thingstad TF, Rassoulzadegan F (1999) Conceptual models for the biogeochemical role of the photic zone microbial food web, with particular reference to the Mediterranean Sea. Prog Oceanogr 44:271-286

Thingstad F, Zweifel U, Rassoulzadegan F (1998) P limitation of heterotrophic bacteria and phytoplankton in the northwest Mediterranean. Limnol Oceanogr 43:88-94

> Thingstad TF, Pérez M, Pelegri S, Dolan J, Rassoulzadegan F (1999) Trophic control of bacterial growth in microcosms containing a natural community from northwest Mediterranean surface waters. Aquat Microb Ecol 18: 145-156

Tilman D, Kiesling R, Sterner R, Kilham SS, Johnson FA (1986) Green, bluegreen and diatom algae: taxonomic differences in competitive ability for phosphorus, silicon and nitrogen. Arch Hydrobiol 106:473-485

Valiela I, Costa JE (1988) Eutrophication of Buttermilk Bay, a Cape Cod coastal embayment: concentrations of nutrients and watershed nutrient budgets. Env Manage 12: $539-553$

Vives F (1993) Aspectes hidrogràfics i planctònics dels voltants de l'Arxipèlag de Cabrera. In: Alcover JA, Ballesteros E, Fornós JJ (eds) Història natural de l'Arxipèlag de Cabrera. CSIC-Edit Moll Mallorca, p 487-502

Waska H, Kim G (2010) Differences in microphytobenthos and macrofaunal abundances associated with groundwater discharge in the intertidal zone. Mar Ecol Prog Ser 407:159-172

Yentsch CS, Menzel DW (1963) A method for the determination of phytoplankton chlorophyll and phaeophytin by fluorescence. Deep-Sea Res 10:221-231

Zohary T, Herut B, Krom MD, Mantoura RFC and others (2005) P-limited bacteria but N and P co-limited phytoplankton in the Eastern Mediterranean: a microcosm experiment. Deep-Sea Res II 52:3011-3023

Submitted: February 1, 2011; Accepted: July 22, 2011

Proofs received from author(s): September 16, 2011 